\title{
CYP2C8 Gene
}

National Cancer Institute

\section{Source}

National Cancer Institute. CYP2C8 Gene. NCI Thesaurus. Code C46071.

This gene plays a role in drug metabolism. It is also involved in the oxidation of both endobiotics and xenobiotics. 